\title{
Selecting squash (Cucurbita sp.) introductions by seed nutritional quality and seed meal
}

\section{Selección de introducciones de zapallo Cucurbita sp. por calidad nutricional en semilla}
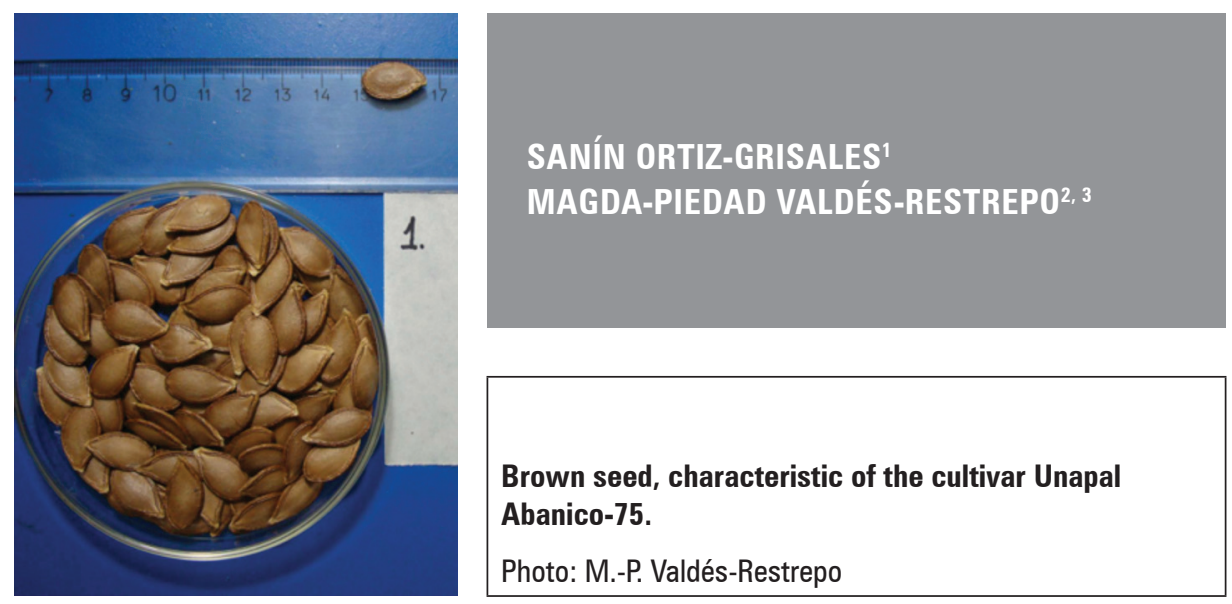

\section{ABSTRACT}

Squash (Cucurbita sp.) is widely used in Colombia as both food and animal feed. However, its seeds are discarded. This study aimed to identify squash genotypes with a high nutritional value in the whole seed meal (WSM) and defatted seed meal (DSM) within a group of 19 introductions (14 of Cucurbita moschata and 5 of C. sororia). For WSM, 70\% of the introductions presented above-average values for extract $(36.9 \%)$ and crude protein (26.34\%); the fiber values were $20.34 \%$ neutral detergent fiber (NDF) and $13 \%$ acid detergent fiber (ADF). For DSM, $57 \%$ of the introductions presented above-average crude protein $(43.5 \%)$ and $52 \%$ above-average crude energy values $\left(4078 \mathrm{cal} \mathrm{g}^{-1}\right)$. Based on the relative feed value (RFV), introductions 1229 , 1200, 1201, 1219 and 1206 were selected for WSM, and 1206 1229, 932, 1200, 786 and 954 were selected for DSM. In the selected C. moschata introductions, parents with general and specific combining abilities for ether extract and crude protein in WSM or high RFV in DSM should be identified. C. soraria introductions 1202 and 954 should be used in crosses that aim to obtain $\mathrm{F}_{2}$ segregants for seeds with a high oil content and high RFV in DSM.

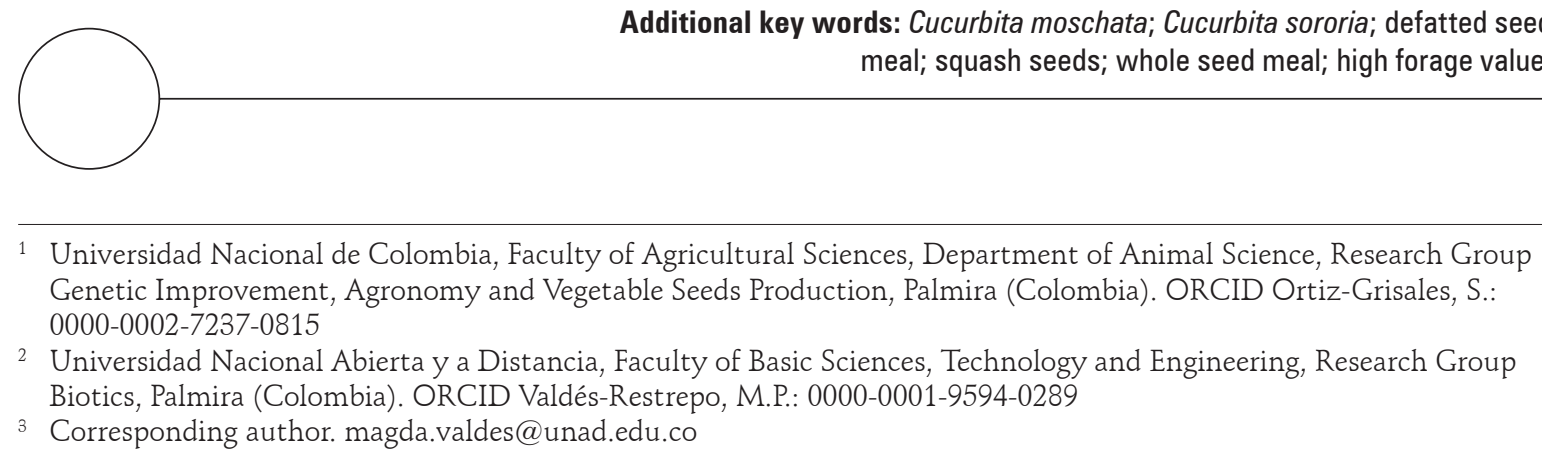
meal; squash seeds; whole seed meal; high forage value. 


\section{RESUMEN}

Zapallo (Cucurbita sp.) se ha utilizado como alimento en humanos y animales. Sin embargo, sus semillas, son descartadas. Por consiguiente, este estudio tuvo como objetivo identificar los genotipos de zapallo con alto valor nutritivo en harina de semilla entera (HSE) y harina de semilla desgrasada (HSD) dentro de un grupo de 19 introducciones (14 de Cucurbita moschata y 5 de C. sororia). En cuanto a la HSE, el 70\% de las introducciones presentaron valores superiores a la media para el extracto de éter $(36.9 \%)$ y proteína cruda $(26.34 \%)$. Con respecto a la HSD, el $57 \%$ de las introducciones presentaron proteína bruta por encima del promedio (43.5\%) y el 52\% tenían valores de energía bruta por encima del promedio (4078 $\mathrm{cal} \mathrm{g}^{-1}$ ). La HSE de zapallo presenta un $20.34 \%$ de fibra detergente neutra y un 13\% de fibra detergente ácida. Con base en al valor de relativo del forraje (VRF), las introducciones 1229, 1200, 1201, 1219 y 1206 se seleccionaron para HSE y 1206 1229, 932, 1200, 786 y 954 para HSD. En las introducciones seleccionadas de C. moschata, la recomendación es identificar a los padres con habilidades combinatorias generales y específicas para el extracto de éter y la proteína bruta en HSE y para una alta VRF en HSD. Las introducciones de C. soraria 1202 y 954 deben usarse en cruzamientos que pretenden obtener segregantes de F2 para semillas con alto contenido de aceite y alta VRF en HSD.

Palabras clave adicionales: Cucurbita moschata; Cucurbita sororia; harina de semilla desgrasada; semillas de zapallo; harina de semilla entera.

Received for publication: 11-05-2019 Accepted for publication: 31-07-2019

\section{INTRODUCTION}

Identification of the place of origin has been the main research topic in Cucurbitas; however, little is known about the seed as a source of energy despite its high content of ethereal extract (Rodríguez et al., 2018). The sororia subspecies includes wild populations with a broad distribution, from Mexico to Nicaragua, which is the wild ancestor of the domesticated species $C$. argyrosperma. The fruits are white with green and have varied sizes. The pericarp is usually coriaceous and is hard to fracture even with a percussion tool, with a bufoid pericarp and bedding (Valdés et al., 2014). The mesocarp can be colorless in some introductions; in others, it has an intense yellow color and bitter taste. Some fruits have a salmon-yellow mesocarp, which, upon, contact with air turns from deep green to completely black in a few minutes after removing the seeds, as seen in C. moschata (Hidalgo and Vallejo, 2014). C. moschata is a domesticated species in South America. Although there is no agreement on the precise area of its domestication, it has been mentioned that northern Colombia is possibly the center of origin (Ortiz et al., 2013). The seeds have different shades of coloration in the testa, ranging from havana to coffee with golden edges; the fruits usually have a soft pericarp, which can be smooth or curled, with soft bufoids, sardines, particular colors, one or two colors in bands or spots and variable format. The mesocarp is orange, ranging from pale orange to deep orange. The matrix has an intense orange; some matrices, upon contact with air, become intense green (Hidalgo and Vallejo, 2014).

The economic value of tropical pastures -the basis of nutrition for cattle, goats, and sheep- has been widely documented (McIlroy, 1973; Roy, 2000; Ramírez et al., 2012; Sánchez et al., 2015). However, the forage that has been used to feed animals in the tropics lacks protein and energy (Cook et al., 2005; Holguín et al. 2015) and must be supplemented with agroindustrial raw materials or cereal and legume grains. New genotypes must be identified that can replace the available feed resources to ensure balanced livestock production, enhancing animal performance while reducing the need to use costly imported grains (Ortiz et al., 2013).

Ruminants, for example, are capable of degrading lowquality forage that is rich in plant cell walls, which is not suitable for feeding most monogastric animals that have enzymatic digestive processes (Pereira et al., 2015) because of multiple symbiotic, physical and mechanical associations that occur in the digestive tract, specifically in the rumen (McSweeney and Mackie, 2012). Starch is fermented into volatile 
fatty acids and nitrogen sources that are degraded to ketoacids and ammonia, the latter being the main source of $\mathrm{N}$ for microbial synthesis (Nikkhah, 2015). The intensity of this degradation process varies, depending on the magnitude of the potential degradable fraction and the retention time in the rumen as a function of forage quality, the amount of ammonia in the substrate and the available energy derived from high-quality grains, which degrade more quickly and yield more nutrients for cattle, improving the nutritional efficiency (Olabisi, 2015). Therefore, research is needed on a new source of nutrients for animals, such as Cucurbita Spp seeds.

The whole seed meal (WSM) from squash cultivar Abanico-75 contained $36.25 \pm 3.25 \%$ ether extract (EE), which was composed of $55.28 \%$ unsaturated fatty acids (of which $55.11 \%$ was linoleic acid). The defatted seed meal (DSM) contained $51.1 \pm 0.95 \%$ protein and $4604.66 \pm 134.08 \mathrm{kcal} \mathrm{kg}^{-1}$ crude energy (CE). The seed starch content ranged from 13 to 28\% (Valdés et al., 2014). In 2009 and 2013, the Vegetables Research Group of the Universidad Nacional de Colombia-Palmira campus studied a collection of butternut squash (Cucurbita moschata Duch.) genotypes from Central America to determine whether the nutritional composition in the WSM and DSM was sufficiently variable to select superior genotypes for farmers or animal feed (Valdés et al. 2014; Ortiz et al., 2013).

The present study aimed to identify squash genotypes with a high nutritional value in WSM and DSM in a group of introductions that belong to the Vegetable Research Program's work collection of the Universidad Nacional de Colombia-Palmira campus.

\section{MATERIALS AND METHODS}

\section{Trial site}

The experiment was carried out during the first semester of 2017 on the Mario Gonzales Aranda Experimental Farm and in the Seeds and Animal Nutrition Labs of the Universidad Nacional de Colombia,

Table 1. Squash introductions used in the quality screening trial.

\begin{tabular}{|c|c|c|c|c|c|}
\hline Serial & Introduction Code & Cucurbita species & Lugar & Municipio & Estado \\
\hline 1 & Unapal Abanico-75 & C. moschata & Palmira & Valle del Cauca & ---- \\
\hline 2 & 419 & C. moschata & Ocozocoautla & Ocozocoautla de espino & Chiapas \\
\hline 3 & 1201 & C. moschata & Tecomatlan & Autlan de navarro & Jalisco \\
\hline 4 & 786 & C. moschata & Eji. Plan de juarez & Xilitla & SLP \\
\hline 5 & 802 & C. moschata & Eji. huichihuayan & Huehuetlan & SLP \\
\hline 6 & 1222 & C. moschata & Teneria del Santuario & Celaya & Guanajuato \\
\hline 7 & 932 & C. moschata & Guayabitos & Choix & Sinaloa \\
\hline 8 & 1219 & C. moschata & La cienaga & El limon & Jalisco \\
\hline 9 & 1213 & C. moschata & Espinal & Ocozocoautla de espino & Chiapas \\
\hline 10 & 1235 & C. moschata & El encanto & Las Margaritas & Chiapas \\
\hline 11 & 1229 & C. moschata & Col. A López Mateos & Tepalcingo & Morelos \\
\hline 12 & 1206 & C. moschata & El chante & Autlan de navarro & Jalisco \\
\hline 13 & 1205 & C. moschata & Ahuacapan & Autlan de navarro & Jalisco \\
\hline 14 & 1200 & C. moschata & El chante & Autlan de navarro & Jalisco \\
\hline 15 & 1202 & C. sororia & El cuastecomate & Ejutla & Jalisco \\
\hline 16 & 1210 & C. sororia & ----- & Amatlan de cañas & Nayarit \\
\hline 17 & 954 & C. sororia & Culiacan & Culiacan & Sinaloa \\
\hline 18 & 1215 & C. sororia & Ejutla & Ejutla & Jalisco \\
\hline 19 & 1207 & C. sororia & El chante & Autlan de navarro & Jalisco \\
\hline Reference & Abanico-75 & C. moschata & & & \\
\hline
\end{tabular}

SLP, San Luis Potosi. 
located in the municipality of Palmira, Colombia (0330'26.8" N 76 18'47.6" W; average annual temperature, $24^{\circ} \mathrm{C} ; 1,000 \mathrm{~m}$ a.s.l.; average annual precipitation, 1,000 mm) (Valdés et al., 2010).

\section{Biological study materials}

The WSM and DSM came from 19 squash introductions: 14 butternut squash (Cucurbita moschata) introductions from Colombia and 5 introductions of a wild Mexican gourd (Cucurbita sororia), which belong to the Vegetable Research Program's work collection, Universidad Nacional de Colombia-Palmira Campus (Tab. 1). The WSM and DFM made from the fruit of squash cultivar Unapal Abanico-75 were used as the reference.

Seed treatment protocol. All squash seed samples were lyophilized and minced in a 2-blade Wiley Mill to obtain $1 \mathrm{~mm}$-sized particles. The EE of the ground and lyophilized WSM and DSM was determined using a Soxhlet extractor, preserved separately in $50 \mathrm{ml}$ Eppendorf tubes kept under refrigerated conditions (between 4 and $12^{\circ} \mathrm{C}$ ) for a subsequent quality analysis based on complete proximate analysis, along with fiber analysis using the Van Soest method (Tab. 2).

Table 2. Proximate and fiber analyses of the butternut squash whole seed meal and defatted seed meal based on dry matter content.

\begin{tabular}{|c|c|c|}
\hline Component & Component determined & Method used \\
\hline Crude protein (CP) & Nitrogen $\times 6.25$ & Kjeldahl \\
\hline Total ashes & Minerals & AOAC 942.05 \\
\hline Ether extract (EE) & Crude fat & Soxhlet \\
\hline Fiber & $\begin{array}{c}\text { Neutral detergent fiber } \\
\text { (NDF), acid detergent fiber } \\
\text { (ADF), lignin }\end{array}$ & Van Soest \\
\hline Crude energy (CE) & Total energy content & $\begin{array}{c}\text { Calorimetric } \\
\text { pump }\end{array}$ \\
\hline
\end{tabular}

\section{Selection of introductions for their nutritional value}

The results of the proximate and fiber analyses were used to select the introductions with the highest nutritional value in the WSM and DSM. The weighted selection index (WSI) was used (Roy, 2000; Valdés et al., 2014) as follows: (1), where $W_{S I} I_{(k)}$ was the standardized selection index for the $k$-th introduction
( $k: 1,2,3 \ldots), P_{i}$ was the weighted factor assigned to $i$-th descriptor (i: $1,2,3 \ldots), \bar{X}_{i(k)}$ was the average of the $i$-th descriptor in the $k$-th introduction, $\bar{X}_{g(i)}$ was the overall average of the collection for the $i$-th descriptor, and $S_{g(i)}$ was the overall standard deviation of the $i$-th descriptor considering the $\mathrm{k}$ introductions.

$$
W S I_{(k)}=\sum_{1}^{19} P i \frac{\left(\bar{X}_{i(k)}-\bar{X}_{g(i)}\right)}{S_{g(i)}}
$$

The WSI value was calculated for each of the 19 introductions based on the following characteristics: ash content, crude protein (CP) and EE in the WSM and ash content, CP and CE in the DSM. The weighting factor $P i$ was assumed to be 0.33 and was equal for all variables, based on the assumption of equality of relative importance when studying an introduction for animal nutrition purposes.

\section{Selecting introductions by relative feed value}

The protocol of Hoffman and Combs (2014) was followed to determine the relative feed value (RFV) of each introduction. The fiber analysis, in terms of neutral detergent fiber (NDF) and acid detergent fiber $(\mathrm{ADF})$, was used to determine the feed value and forage quality. The following general model was used:

$R F V=(D D M \times D M I) / 1.29$

where $D D M$ was digestible dry matter $=88.9-(0.779$ $\times \% \mathrm{ADF}$ ) and $D M I$ was dry matter intake (\% liveweight $)=120 /(\% \mathrm{NDF})$.

The data were processed using Excel and subsequently analyzed using the SAS (statistical analysis software) statistical package (SAS, 2013).

\section{RESULTS AND DISCUSSION}

\section{Proximate characterization of the squash whole seed meal and defatted seed meal}

The dry matter content of the WSM was higher than that of the DSM, probably because the DSM components (sugars, starches) are fat-free and, as a result, are not protected from atmospheric humidity, possibly expressing some sort of hygroscopic ability (Tab. 3 and 4). 
In general, the average ash and CP contents of the WSM were lower than those of the DSM, while the CE was higher in the WSM than in the DSM. This was due to the fact that oil, the largest source of energy, was eliminated from the WSM during the ether extraction, whereas in the DSM, the mass ratios favored the remaining metabolites, especially starch and CP (Tab. 3 and 4).

The overall mineral content, represented by the ash content, in the WSM and DSM in this study was higher than the ash content in the squash WSM (3.9\%) reported by Ortiz et al. (2009) and that of peanut seed meal (2.6\%) reported by Pascual et al. (2006) (Tab. 3 and 4). The reference material, a WSM made from the fruit of cultivar Abanico-75, presented aboveaverage mineral ash content values (6.18-7.62\%), as compared with the WSM (4.13\%) and DSM (5.31\%) (Tab. 3).

The three introductions with the higher EE contents were 1200 (43.61\%), 1219 (42.03\%) and Unapal Abanico-75 (41.86\%). Based on this information and reports by Ortiz et al. (2009), squash seed can be considered an oleaginous raw material.

Of the 19 studied introductions, $70 \%$ presented an above-average EE content (36.9\%) in the seeds (Tab. 3). According to Younis et al. (2000), the EE of squash seeds is higher than that of sunflower seeds (36\%), except in the case of squash introduction 802 (30.43\%), agreeing with results found by Roy (2000) when compared with maize (5\% EE) and linseed $(20.7 \% \mathrm{EE})$.

Table 3. Nutritional value and weighted selection index (WSI) for whole seed meal of 19 squash introductions and cultivar Abanico-75 (the latter used as the reference).

\begin{tabular}{|c|c|c|c|c|c|c|c|}
\hline Introduction & $\begin{array}{l}\text { Dry Matter } \\
(\%)\end{array}$ & $\begin{array}{l}\text { Ash } \\
(\%)\end{array}$ & $\begin{array}{c}\text { Ether extract } \\
(\%)\end{array}$ & $\begin{array}{c}\text { Crude protein } \\
(\%)\end{array}$ & $\begin{array}{l}\text { Crude energy } \\
\left(\text { cal g }^{-1}\right)\end{array}$ & WSI & Ranking \\
\hline 1205 & 94.17 & 4.41 & 35.96 & 23.99 & 6075.62 & -0.1022 & 12 \\
\hline 1207 & 94.79 & 4.46 & 38.77 & 26.45 & 5935.76 & 0.2457 & 8 \\
\hline 1202 & 93.85 & 4.12 & 37.84 & 29.91 & 5760.64 & 0.3211 & 7 \\
\hline 1213 & 94.29 & 4.31 & 34.75 & 30.0 & 5691.34 & -0.2040 & 14 \\
\hline 1206 & 94.58 & 3.05 & 33.75 & 28.0 & 5740.3 & -0.8258 & 19 \\
\hline 1229 & 95.03 & 4.27 & 41.37 & 27.12 & 6097.11 & 0.3325 & 6 \\
\hline 1201 & 93.57 & 4.35 & 38.9 & 30.22 & 6523.15 & 0.4998 & 4 \\
\hline 1200 & 93.62 & 4.13 & 43.61 & 29.2 & 5747.29 & 0.5691 & 2 \\
\hline 419 & 92.31 & 3.62 & 37.89 & 21.33 & 5002.31 & -0.5839 & 17 \\
\hline 1210 & 93.12 & 3.38 & 37.03 & 26.87 & 5778.83 & -0.2950 & 16 \\
\hline 932 & 93.37 & 4.69 & 34.84 & 27.31 & 5882.01 & 0.2365 & 9 \\
\hline 1219 & 94.26 & 4.27 & 42.03 & 29.35 & 6112.84 & 0.5396 & 3 \\
\hline 802 & 93.42 & 4.62 & 30.43 & 24.98 & 5657.46 & -0.1844 & 13 \\
\hline 1222 & 94.23 & 3.62 & 41.56 & 27.76 & 5288.96 & 0.0952 & 10 \\
\hline Abanico-75-S* & 93.38 & 3.07 & 41.86 & 21.81 & 5948.52 & -0.6129 & 18 \\
\hline 1235 & 93.08 & 4.77 & 39.43 & 28.4 & 5880.92 & 0.5722 & 1 \\
\hline Abanico-75- $F^{* *}$ & 88.45 & 6.18 & 10.01 & 12.68 & 3818.87 & -1.3925 & 20 \\
\hline 786 & 93.93 & 4.47 & 38.9 & 27.8 & 4405.45 & 0.3631 & 5 \\
\hline 954 & 93.31 & 3.77 & 38.38 & 27.8 & 5915.85 & 0.0193 & 11 \\
\hline 1215 & 93.41 & 3.22 & 41.07 & 25.94 & 5926.01 & -0.2543 & 15 \\
\hline Mean & 93.5 & 4.13 & 36.91 & 26.34 & 5659.46 & & \\
\hline LSD (5\%) & 0.89 & 0.47 & 4 & 2.678 & 408.34 & & \\
\hline CV $\%$ & 1.45 & 17.45 & 19.26 & 15.41 & 10.93 & & \\
\hline
\end{tabular}

* Whole seed meal made from the fruit of cultivar Abanico-75 (reference). ${ }^{* *}$ Defatted seed meal made from the fruit of cultivar Abanico-75 (reference). 
Of the studied squash introductions, $70 \%$ presented an above-average $\mathrm{CP}$ content in the seeds (average $=$ $26.34 \%$ ) (Tab. 3). The CP values were similar to or higher than those for peanut (Arachis hypogea), 26.0\%; Canavalia grain (Canavalia ensiformis), 16-23\%; cotton seed (Gossypium spp.), 12-22\%; and Nima bean (Phaseolus vulgaris), 16-20\%. For the seed CE, 65\% of the introductions presented above-average values $\left(5659.46 \mathrm{kcal} \mathrm{kg}^{-1}\right)$, surpassing that of sunflower seed $\left(5,353 \mathrm{kcal} \mathrm{kg}^{-1}\right)$ (Arija et al., 1999) (Tab. 3).

The WSI for the nutritional value of the squash seeds showed that $57 \%$ of the introductions were aboveaverage in several of the studied variables, with 1235 , 1200, 1219 and 1201 ranking first (Tab. 3).
Of the introductions included in this study, 57\% presented above-average CP values (43.5\%) in the DSM, presenting higher values than palm kernel cakes $(14 \%)$, cotton $(29.5 \%)$, rapeseed $(34.5 \%)$, copra (21\%) (Chatterjee and Walli, 2002) and Jatropha curcas fruits (Rodriguez et al., 2016). In addition, the CP value in the DSM of introductions 1205 (46.16\%), $1229(52.48 \%)$ and $1222(52.22 \%)$ as well as that of cultivar Abanico-75 (51.33\%) was higher than that of soybean meal (46\%) (Tab. 4).

For the CE in the DSM, $52 \%$ of the introductions presented above-average values $\left(4,078 \mathrm{cal} \mathrm{g}^{-1}\right)$. Introduction 1201 presented the highest energy content in the WSM $\left(6,523.15 \mathrm{cal} \mathrm{g}^{-1}\right)$ and introduction 1202

Table 4. Nutritional value and weighted selection indexes (WSI) for defatted seed meal of 19 squash introductions and cultivar Abanico-75 (the latter used as the reference).

\begin{tabular}{|c|c|c|c|c|c|c|}
\hline Introduction & $\begin{array}{c}\text { Dry matter } \\
(\%)\end{array}$ & $\begin{array}{l}\text { Ash } \\
(\%)\end{array}$ & $\begin{array}{l}\text { Crude protein } \\
\qquad(\%)\end{array}$ & $\begin{array}{c}\text { Energy } \\
\left(\text { cal g }^{-1}\right)\end{array}$ & WSI & Ranking \\
\hline 1205 & 89.91 & 5.36 & 46.16 & 3828.14 & -0.5603 & 19 \\
\hline 1207 & 91.64 & 5.63 & 41.31 & 4107.12 & 0.1055 & 7 \\
\hline 1202 & 90.1 & 5.2 & 45.82 & 4290.07 & 0.6107 & 4 \\
\hline 1213 & 90.21 & 5.53 & 42.76 & 4035.63 & -0.0683 & 11 \\
\hline 1206 & 90.41 & 3.6 & 40.63 & 4134.69 & -0.5465 & 18 \\
\hline 1229 & 87.08 & 5.36 & 52.84 & 4195.82 & 0.6674 & 3 \\
\hline 1201 & 89.95 & 5.76 & 39.81 & 4092.93 & 0.0580 & 8 \\
\hline 1200 & 89.98 & 5.05 & 40.48 & 4197.76 & 0.1181 & 6 \\
\hline 419 & 90.56 & 4.73 & 37.61 & 4167.96 & -0.1762 & 15 \\
\hline 1210 & 91.66 & 4.59 & 39.77 & 4053.16 & -0.4542 & 17 \\
\hline 932 & 91.78 & 5.68 & 44.37 & 3935.31 & -0.2272 & 16 \\
\hline 1219 & 90.1 & 5.51 & 44.8 & 4053.37 & 0.0462 & 9 \\
\hline 802 & 90.2 & 6.41 & 38.96 & 3954.64 & -0.1190 & 13 \\
\hline 1222 & 91.43 & 4.47 & 52.22 & 4149.74 & 0.2139 & 5 \\
\hline Abanico-75-S* & 91.84 & 4.03 & 51.33 & 4129.52 & -0.0245 & 10 \\
\hline 1235 & 90.17 & 6.82 & 49.82 & 4129.76 & 0.8853 & 1 \\
\hline Abanico-75-F** & 89.73 & 7.62 & 11.16 & 3825.62 & -1.0532 & 20 \\
\hline 786 & 89.75 & 5.97 & 49.78 & 4220.64 & 0.8339 & 2 \\
\hline 954 & 90.2 & 4.62 & 51.89 & 3996.41 & -0.1573 & 14 \\
\hline 1215 & 89.92 & 4.38 & 49.73 & 4074.61 & -0.1087 & 12 \\
\hline Mean & 90.33 & 5.31 & 43.56 & 4078.64 & & \\
\hline LSD (5\%) & 0.6 & 0.63 & 6.01 & 81.18 & & \\
\hline CV\% & 1.16 & 17.97 & 20.92 & 3.017 & & \\
\hline
\end{tabular}

* Whole seed meal made from the fruit of cultivar Abanico-75 (reference). ${ }^{* *}$ Defatted seed meal made from the fruit of cultivar Abanico-75 (reference). 
presented the highest energy content in the DSM $\left(4,90.07 \mathrm{cal} \mathrm{g}^{-1}\right)$ (Tab. 4).

Introductions 1235, 786, 1229 and 1202 ranked first based on the WSI, presenting outstanding nutritional values (Tab. 4).

Based on the data collected in this study, all of the WSMs and DSMs presented higher nutritional values than the raw materials on the market. This study aimed to determine which introductions could serve as potential parents in future breeding efforts and selection processes conducted by the university's Vegetable Research Program. Based on the WSI, those introductions presenting the best proximate performance in terms of WSM were 1235, 1200, 1219, 1201, 954 and 786; in terms of the DSM, introductions 1235, 786, 1229, 1202 and 1222 had the best performance. Likewise, introductions 1235 and 786 ranked first in both the WSM and DSM, based on the comprehensive weighted value.

\section{Fiber quality of whole seed and seed meal of squash introductions}

Both food and animal feed industries require raw material with minimal values of NDF, ADF and lignin, particularly in the case of animal nutrition, where the high digestibility of nutrients in ruminants and monogastric animals that present enzymatic digestive processes is associated with a low NDF and ADF with respect to total fiber content. The RFV assigned to the WSM and DSM in Tab. 5 and 6 assumed that the high RFVs mean that these introductions have a high biological value. Based on the foregoing, the best introductions in terms of RFV for the WSM were 1229, 1200, 1201, 1219 and 1206 (Tab. 5).

Table 5. Relative feed value (RFV) of whole seeds of 19 squash introductions and cultivar Abanico-75 (the latter used as the reference).

\begin{tabular}{|c|c|c|c|c|c|c|}
\hline Introduction & $\begin{array}{c}\text { Neutral detergent } \\
\text { fiber } \\
(\%)\end{array}$ & $\begin{array}{c}\text { Acid detergent } \\
\text { fiber } \\
(\%)\end{array}$ & $\begin{array}{c}\text { Dry matter } \\
\text { consumption }{ }^{1} \\
\text { (\% liveweight) } \\
\end{array}$ & $\begin{array}{c}\text { Digestible dry } \\
\text { matter }^{2} \\
(\%)\end{array}$ & $\mathrm{RFV}^{3}$ & Ranking \\
\hline 1205 & 25.6 & 18.46 & 4.69 & 74.52 & 270.78 & 12 \\
\hline 1207 & 23.16 & 17.39 & 5.18 & 88.76 & 356.53 & 7 \\
\hline 1202 & 38.23 & 27.03 & 3.14 & 88.69 & 215.80 & 16 \\
\hline 1213 & 22.75 & 15.46 & 5.27 & 88.78 & 363.01 & 6 \\
\hline 1206 & 21.94 & 17.83 & 5.47 & 88.76 & 376.34 & 5 \\
\hline 1229 & 18.76 & 11.82 & 6.40 & 88.81 & 440.36 & 1 \\
\hline 1201 & 20.17 & 15.75 & 5.95 & 88.78 & 409.44 & 3 \\
\hline 1200 & 19.92 & 15.43 & 6.02 & 88.78 & 414.59 & 2 \\
\hline 419 & 31.31 & 23.77 & 3.83 & 88.71 & 263.58 & 13 \\
\hline 1210 & 26.59 & 17.08 & 4.51 & 88.77 & 310.54 & 9 \\
\hline 932 & 28.71 & 22.09 & 4.18 & 88.73 & 287.49 & 10 \\
\hline 1219 & 21.03 & 13.53 & 5.71 & 88.79 & 392.77 & 4 \\
\hline 802 & 39.22 & 31.5 & 3.06 & 88.65 & 210.27 & 19 \\
\hline 1222 & 38.45 & 30.01 & 3.12 & 88.67 & 214.51 & 18 \\
\hline Abanico-75-S* & 29.75 & 13.74 & 4.03 & 78.20 & 244.51 & 14 \\
\hline 1235 & 33.58 & 27.45 & 3.57 & 67.52 & 187.03 & 20 \\
\hline 786 & 30.59 & 13.7 & 3.92 & 78.23 & 237.89 & 15 \\
\hline 954 & 25.16 & 18.46 & 4.77 & 74.52 & 275.52 & 11 \\
\hline Abanico-75-F** & 22.71 & 6.64 & 5.28 & 83.73 & 342.96 & 8 \\
\hline 1215 & 30.59 & 23.22 & 3.92 & 70.81 & 215.34 & 17 \\
\hline Mean & 27.41 & 19.01 & 4.60 & 84.06 & 301.46 & \\
\hline LSD 5\% & 4.23 & 4.27 & 0.67 & 4.75 & 52.55 & \\
\hline CV \% & 23.43 & 34.06 & 22.37 & 8.56 & 26.42 & \\
\hline
\end{tabular}

${ }^{1}$ Estimated as $120 /$ (\% neutral detergent fiber). ${ }^{2}$ Estimated as $88.9-\left(0.779 \times \%\right.$ acid detergent fiber). ${ }^{3}$ Estimated as (digestible dry matter $x$ dry matter intake) / 1.29. * Whole seed meal made from the fruit of cultivar Abanico-75 (reference). ${ }^{* *}$ Defatted seed meal made from the fruit of cultivar Abanico-75 (reference). 
As indicated above, after the seed oil extraction, the DSM acquired a special biologic value because of its high protein content. However, what determines whether the RFV of the DSM is apt for cattle nutrition is the level of fiber (NDF or ADF). Introductions 1229, 932, 1200, 786 and 954 ranked first for this variable (Tab. 6).

Based on the selected introductions, the recommendation is to identify $C$. moschata parental materials with both a general combining ability and a specific combining ability for EE and CP in the WSM and for a high RFV in both the WSM and DSM (Ortiz et al., 2013).

A crossbreeding process should be carried out with C. sororia introductions 1202 and 954 to obtain superior $\mathrm{F}_{2}$ segregants for oleaginous and protein grain (Ortiz et al. 2013).

\section{CONCLUSIONS}

The squash WSM and the DSM meal derived thereof presented a high nutritional value with the potential to replace protein and oleaginous grains in ruminant feed.

Of the introductions submitted to proximate analysis to determine nutritional value, $10 \%$ of the C. sororia introductions (954 and 1215) and 26\% of the $C$. moschata introductions (786, 1200, 1219, 1229 and 1235) ranked high in terms of quality.

Based on the RFV, introductions 1229, 1200, 1201 , 1219 and 1206 were selected for the WSM, and 1206, 1229, 932, 1200, 786 and 954 were selected for the DSM.

In the case of $C$. moschata introductions 1200,1201 , 1206, 1213, 1219 and 1229, parents with both general

Table 6. Relative feed value (RFV) of defatted seed meal made from 19 squash introductions and cultivar Abanico-75 (the latter used as the reference).

\begin{tabular}{|c|c|c|c|c|c|c|}
\hline Introduction & $\begin{array}{l}\text { NDF } \\
(\%)\end{array}$ & $\begin{array}{l}\text { ADF } \\
(\%)\end{array}$ & $\begin{array}{c}\text { Dry matter consumption }{ }^{1} \\
\text { (\% liveweight) }\end{array}$ & $\begin{array}{c}\mathrm{DDM}^{2} \\
(\%)\end{array}$ & $\mathrm{RFV}^{3}$ & Ranking \\
\hline 1205 & 18.95 & 17.72 & 6.33 & 75.10 & 368.64 & 11 \\
\hline 1207 & 22.46 & 13.99 & 5.34 & 78.00 & 323.06 & 18 \\
\hline 1202 & 35.25 & 25.26 & 3.40 & 69.22 & 182.68 & 20 \\
\hline 1213 & 20.7 & 10.53 & 5.80 & 80.70 & 362.64 & 12 \\
\hline 1206 & 19.68 & 15.67 & 6.10 & 76.69 & 362.51 & 13 \\
\hline 1229 & 13.58 & 8.38 & 8.84 & 82.37 & 564.25 & 2 \\
\hline 1201 & 19.97 & 10.85 & 6.01 & 80.45 & 374.74 & 9 \\
\hline 1200 & 17.16 & 9.73 & 6.99 & 81.32 & 440.83 & 4 \\
\hline 419 & 21.36 & 12.6 & 5.62 & 79.08 & 344.42 & 15 \\
\hline 1210 & 20.51 & 16.35 & 5.85 & 76.16 & 345.44 & 14 \\
\hline 932 & 16.21 & 10.23 & 7.40 & 80.93 & 464.43 & 3 \\
\hline 1219 & 20.1 & 7.37 & 5.97 & 83.16 & 384.86 & 7 \\
\hline 802 & 29.26 & 14.9 & 4.10 & 77.29 & 245.73 & 19 \\
\hline 1222 & 21.86 & 13.01 & 5.49 & 78.77 & 335.18 & 16 \\
\hline Abanico-75-S* & 19.55 & 11.87 & 6.14 & 79.65 & 379.01 & 8 \\
\hline 1235 & 19.69 & 12.46 & 6.09 & 79.19 & 374.14 & 10 \\
\hline 786 & 16.84 & 19.29 & 7.13 & 73.87 & 408.07 & 5 \\
\hline 954 & 18.78 & 10.51 & 6.39 & 80.71 & 399.80 & 6 \\
\hline Abanico-75-F** & 12.33 & 5.4 & 9.73 & 84.69 & 638.97 & 1 \\
\hline 1215 & 22.59 & 13.13 & 5.31 & 78.67 & 323.96 & 17 \\
\hline Mean & 20.34 & 12.96 & 6.20 & 78.80 & 381.16 & \\
\hline LSD 5\% & 3.28 & 2.96 & 0.92 & 2.30 & 64.49 & \\
\hline CV \% & 24.45 & 34.63 & 22.63 & 4.43 & 25.65 & \\
\hline
\end{tabular}

${ }^{1}$ Estimated as 120 / (\% neutral detergent fiber). ${ }^{2}$ Estimated as 88.9 - $(0.779 \times \%$ acid detergent fiber).

${ }^{3}$ Estimated as (digestible dry matter $x$ dry matter intake) / 1.29. * Whole seed meal made from the fruit of cultivar Abanico-75 (reference). ${ }^{* *}$ Defatted seed meal made from the fruit of cultivar Abanico-75 (reference). NDF, neutral detergent fiber. ADF, acid detergent fiber. DDM, Digestible dry matter. 
and specific combining abilities for oil and CP contents in the WSM and for high RFV in both the WSM and DSM should be identified.

A crossbreeding process should be carried out with $C$. sororia introductions 1202 and 954 to obtain $F_{2}$ segregants for seeds with a high oil value in the WSM, as well as for a high RFV in the DSM.

Conflict of interests: this manuscript was prepared and reviewed with the participation of al authors, who declare that there exists no conflict of interest that puts at risk the validity of the presented results.

\section{ACKNOWLEDGMENTS}

The authors want to extend sincere thanks to the Genetic Improvement, Agronomy, and Vegetable Seed Production Program of the Universidad Nacional de Colombia-Palmira Campus.

\section{BIBLIOGRAPHIC REFERENCES}

Arija, L., A. Viveros, A. Brenes, and R. Canales. 1999. Estudio del valor nutricional de la semilla de girasol entera descascarillada en raciones de pollos broiler y su efecto sobre la concentración de ácidos grasos en la grasa abdominal. Arch. Zootec. 48(183), 249-259.

Chatterjee, A. and T.K. Walli. 2002. Comparative evaluation of protein quality of three commonly available oilseed cakes by in vitro and in sacco method. Indian J. Dairy Sci. 55(6), 350-355.

Cook, B.G., B.C. Pengelly, S.D. Brown, J.L. Donnelly, D.A. Eagles, M.A. Franco, J. Hanson, B.F. Mullen, I.J. Partridge, M. PETER, and R. Schultze-Kraft. 2005. Tropical Forages: an interactive selection tool [CD-ROM], CSIRO, DPI\&F(Old), CIAT and ILRI, Brisbane, Australia.

Hidalgo, H.R. and C.F.A. Vallejo. 2014. Bases para el estudio de recursos genéticos de especies cultivadas. Universidad Nacional de Colombia, Palmira, Colombia.

Hoffman, P. and D. Combs. 2014. Using NDF digestibility in ration formulation, UW-Madison Dairy Science Department Marshfield Agricultural Research. Focus on Forage 6(3), 1-4.

Holguín, V.A., G.S. Ortiz, N.A. Velasco, and D.J. Mora. 2015. Evaluación multicriterio de 44 introducciones de Tithonia diversifolia (hemsl.) A. Gray en Candelaria, Valle del Cauca. Rev. Med. Vet. Zoot. 62(2):57-72. Doi: http://dx.doi.org/10.15446/rfmvz

Mcsweeney, C. and R. Mackie. 2012. Micro-organisms and ruminant digestion: state of knowledge, trends and future prospects. In: http://www.fao.org/docrep/016/ me992e/me992e.pdf; consulted: February, 2019.

Mcilroy, R.J. 1973. Introducción al cultivo de los pastos tropicales, Limusa, México DF.

Nikkhah, A. 2015. Multisource starch for optimal rumen and ruminant integrity. J. Adv. Dairy Res. 3, 4. Doi: 10.4172/2329-888X.1000e130

Olabisi, A.D. 2015. Degradation kinetics of carbohydrate fraction of commercial concentrate feeds for weaned calves, heifers, lactating and dry dairy cattle. MSc thesis. University of South Africa, Pretoria, South Africa.

Ortiz, G.S., L.S. Pasos, A.X. Rivas, R.M.P. Valdés, and C.F.A. Vallejo. 2009. Extracción y caracterización de aceite de semillas de zapallo. Acta Agron. 58, 145-151.

Ortiz, G.S., C.F.A. Vallejo, G.D. Baena, S.E.I. Estrada, and R.M.P. Valdés. 2013. Zapallo para consumo en fresco y fines agroindustriales: investigación y desarrollo. Feriva, Cali, Colombia.

Pascual, CH.G., M.S. Molina, S.C. Morales, G.K. Valdivia, and J.F. Quispe. 2006. Extracción y caracterización de aceite de diez entradas de semilla de maní (Arachis hypogaea L.) y elaboración de maní bañado con chocolate. Mosaico Cient. 3(1), 2213-2216.

Pereira, V.T.N., E. Detmann, and S.C. Batista. 2015. Recent advances in evaluation of bags made from different textiles used in situ ruminal degradation. Can. J. Anim. Sci. 95, 493-498. 10.1139/cjas-2017-0064

Ramírez, B.L., P. Lavelle, J.A. Orjuela, and O. Villanueva. 2012. Caracterización de fincas ganaderas y adopción de sistemas agroforestales como propuesta de manejo de suelos en Caquetá, Colombia. Rev. Col. Cienc. Pecu. 25, 391-401.

Rodríguez C.R.M., Suárez H.J. and Támbara H.Y. 2016. Caracterización de la torta obtenida del prensado del fruto de Jatropha curcas. Pastos Forrajes 39(1), 72-75.

Rodríguez, R.R.A., R.M.P. Valdés, and G.S. Ortiz. 2018. Características agronómicas y calidad nutricional de los frutos y semillas de zapallo Cucurbita sp. Rev. Colomb. Cienc. Anim. Recia 10(1), 86-97. Doi: https:// doi.org/10.24188/recia.v10.n1.2018.636

Roy, D. 2000. Plant breeding analysis and exploitation of variation, Alpha Science International, Pangbourne, UK. In: https://www.amazon.com/Plant-Breeding-Analysis-Exploitation-Variation/dp/1842650068; consulted: March, 2018.

Sánchez, V., G. Delreal, C. Plazas, and G. Pérez. 2015. Factibilidad económica de la asociación maíz-pasto en el establecimiento de un sistema silvopastoril en el piedemonte llanero de Colombia. Pastos Forrajes 38(1), 73-79.

SAS. 2013. User's guide: statistics. Statistical Analysis System versión 9.4. SAS Institute Inc., Cary, NC. 
Valdés, R.M.P., G.S. Ortiz, and C.F.A. Vallejo. 2014. Efectos heteróticos para el carácter extracto etéreo en la semilla de zapallo Cucurbita moschata Duch. Rev. U.D.C.A Act. \& Div. Cient. 17(2), 371-379.

Valdés, R.M.P., G.S. Ortiz, G.D. Baena, and C.F.A. Vallejo. 2010. Evaluación de poblaciones de zapallo (Cucurbita moschata) por caracteres de importancia agroindustrial. Acta Agron. 29(1), 91-96.

Younis, Y.M., S. Ghirmay, and S.S. Al-Shihry. 2000. African Cucurbita pepo L.: properties of seed and variability in fatty acid composition of seed oil. Phytochemistry 54, 71-75. 10.1016/j.phytochem.2018.01.007 